\title{
Sodomy in India: Sex Crime or Human Right?
}

\section{Sumit Baudh}

\section{Introduction}

Celebrating the 58th anniversary of Indian Independence in 2005, the Prime Minister of India, Dr Manmohan Singh, urged every Indian to contemplate what 'independence' meant. Are ordinary people in India any more independent or autonomous than they were under British colonisation? If so, then autonomous of what and from whom? It may have come to political leaders who acquired high positions in a new government. That autonomy meant a new regime, and that its constituent office bearers were no longer accountable to Britain. But the new regime was heir to the British colonial government, not to the freedom fighters (Kannabiran 2004: 27); it inherited the laws and administration of colonial India. $A$ vast body of English laws not only survived in an independent India, but continue to evolve by way of amendments, abolition or judicial interpretation. One colonial law that has remained since its inception in 1860, is Section 377 of the Indian Penal Code (IPC):

\section{Unnatural Offences \\ Whoever voluntarily has carnal intercourse against the order of nature with any man, woman or animal shall be punished with imprisonment for life, or with imprisonment of either description for a term which may extend to ten years, and shall also be liable to fine. (Ranchhoddas and Thakore 2002: 1818) ${ }^{1}$}

In this article, I argue that Section 377 is an assault on the personal liberty of every free Indian. It violates autonomy, independence, free will and sovereignty of the people over their own bodies. My analysis is limited to consensual sexual activity between adults, ruling out rape or child abuse; and is further limited to the judicial scrutiny of human rights.

\section{Defining sexualities}

There is a wide spectrum of sexual acts, practices and identities the world over. The existing language of sexuality and human rights, as it has evolved out of judicial scrutiny in cases from outside of India, is largely rooted in the context of same sex sexualities and transgender identities. The movement around sexual rights has borrowed from the existent language of human rights, be that in demanding decriminalisation of sodomy, anti-discrimination at the workplace, or same sex civil partnership/marriage. The rights most frequently engaged have ranged from privacy and equality, to life and human dignity.

What form sexuality takes depends on a range of factors: personal temperament, conservative or liberal values, a sense of propriety or impropriety, and so on. Regardless of its manifestation, dormant or otherwise, sexuality remains an integral component of human experience. Why must expressions of sexuality have to be justified in terms of rights to privacy, to equality, to human dignity? The same range of rights applied to sexuality implicitly endorses what can be called sexual autonomy. The integral nature of sexuality to human experience, I argue here, calls for a distinct human right, namely the right to sexual autonomy (RSA).

The subject of sexuality poses a peculiar definitional challenge, not entirely because the subject is expansive, rather that terminology is a matter of ideological or contextual preference. Some scholars seek to reclaim the term 'homosexual' in an endeavour to give the term a breadth and modernity it has really never had (Macdougall 2000). Others refuse to use 'homosexual' because it is irrevocably tainted by years of use in a pejorative sense (Wintemute 1994). My definitional preference in this article is contextual. My analysis focuses on Section 377 and asks: What is the status of sexuality in 
Section 377? What is 'carnal intercourse against the order of nature'? The primary questions I will address will be: is not the offence of 'carnal intercourse' directly repugnant to the rights to sexual autonomy? If so, does defining a right to sexual autonomy more effectively challenge the notion of 'unnatural offences' in comparison with arguments of privacy, equality, life and/or human dignity?

\section{Compulsory heterosexuality}

What does Section 377 have to say about sex, sexuality or sexual orientation? Nothing on the face of it. A plain reading of the law reveals little and is actually quite ambiguous. To begin with, what does 'carnal intercourse against the order of nature' actually mean?

The available case law makes frequent references to bestiality, buggery and biblical notions of the sin of Gomorrah and the sin of Sodom. That in itself is of little help. The meaning of sodomy has varied across centuries, continents and cultures. ${ }^{2}$ Even its legal interpretation varies from one jurisdiction to another. Legal definitions of buggery and bestiality are similarly difficult to capture. There is a hint in the statutory explanation appended to Section 377. It states that 'penetration' is sufficient to constitute 'carnal intercourse', but does not clarify penetration of what and by what? From a reading of case law, it appears that penile penetration (of the anus or the mouth) is what is being alluded to. ${ }^{3}$ Even penile masturbation of one person by another is considered penetration. ${ }^{4}$

In a study of Indian judgements under Section 377, a total of 46 cases reveals that more than 60 per cent of cases deal with child sexual abuse by men. Out of these, 20 cases involve male children and ten involve female (Narrain 2004: 55). Not that consent is at all an ingredient of the offence, but all these 30 cases are obviously non-consensual. Even in those cases that do involve consensual adults, there is no judicial scrutiny over the element of consent. Some men in these cases are referred to as 'habitual sodomite/catamite' but the judgements are emphatic that prior sexual history or the fact that the accused male wore female attire is of no relevance. Gender and sexuality have thus found little open articulation in the Indian judicial discourse. It is consistently and implicitly held that only penile-vaginal penetration conforms to the order of nature.
The element of consent has been obliquely considered in a divorce case. In this case, the wife alleged cruelty, caused by repeated acts of penile-anal penetration by the husband. It was held that a husband could indeed be 'guilty of sodomy on his wife if she was not a consenting party'. ${ }^{5}$ Although a civil case (as opposed to being a criminal prosecution under Section 377), it is a significant remark on the element of consent. What indeed if a woman consents to 'sodomy' with a man? The question has apparently not caught the judicial imagination.

There was a public scandal in Delhi in December 2004 over an oral sex episode between a boy and a girl, both in their mid-teens. The boy recorded the act on his mobile camera-phone. Later, through a multimedia messaging service (MMS), he circulated the video clip to some of his friends. The clip eventually found its way onto the internet, and was available for public view and purchase. There was a police investigation and the boy was arrested, although not under Section 377 (The Hindu 2004). It did not catch media attention, or police investigation, that penile-oral penetration is an 'unnatural offence', and that the girl was equally liable. Had it been a boy in place of the girl, it might have had very different implications: they could both face imminent and real risk of prosecution under Section 377.

In January 2006, four men were arrested in Lucknow, the capital of Uttar Pradesh, under Section 377. Without any instigation or complaint, the police had traced the phone number of one of the accused on a gay website, and arranged a meeting. The police then forced him to call his friends, three of whom actually turned up. All four were arrested under a false case of having sex in public. In this sting operation, four innocent persons were thus prosecuted in an obviously fabricated case only because of their perceived sexual identity. ${ }^{6}$

As evidenced in the oral sex case in Delhi, a consensual heterosexual act, even if it is not penile-vaginal penetration, is unlikely to be the subject of Section 377. On the other hand, the four men in Lucknow are currently facing prosecution because of their (homo)sexual identity. The underlying and unquestioned premise is that heterosexuality is 'normal' or 'natural'. Conversely, all that is outside of this heterosexuality is 'abnormal' or 'unnatural'. By sanctioning what is 'unnatural', namely 
non-heterosexual sex, the law makes it compulsory that sexual activity be sought exclusively within the boundaries of heterosexuality - between a man and woman. Section 377 in effect imposes compulsory heterosexuality (Menon 2005). It takes away the erotic and sexual self-determination of every person.

This carries special significance in the context of laws that emerged in or are based on colonial regimes. Claiming Bahamian women's erotic and sexual autonomy, Jacqui Alexander (1997) argues that heteropatriarchy is used to continue and perpetuate a colonial inheritance and to enable the political and economic processes of re-colonisation. She defines re-colonisation as 'the attempts by the state, and the global economic interests it represents, to achieve a psychic, sexual and material usurpation of the selfdetermination of the Bahamian people' (Alexander 1997: 63-100). In a similar vein, an instrument of heteropatriarchal oppression, Section 377 enables the state to stigmatise, persecute and place under constant surveillance and control those who have sex in ways other than penile-vaginal penetration.

\section{Existing legal arguments}

Sodomy laws like Section 377 have been a subject of judicial review the world over. The European Court of Human Rights declared such laws as violations of the right to privacy. ${ }^{7}$ A similar stand was later taken by the United Nations Human Rights Committee. ${ }^{8}$ The Supreme Court of the United States has held that sodomy laws violate both privacy rights and equal protection under the law. ${ }^{9}$ The Constitutional Court of South Africa has ruled that such a law violates the right to privacy, the right to equality, and also the right to human dignity. ${ }^{10}$

The three broad strands of legal arguments that emerge out of judicial decriminalisation are thus privacy, equality and human dignity. ${ }^{11}$ In the privacy argument, everyone's choice of sexual conduct is seen as a private affair, which does not warrant undue state intervention. Indulgence in 'carnal intercourse against the law of nature' thus becomes a fundamental choice. In the equality rights argument, sexual orientation is seen as an immutable status, similar to phenomena of race or sex. 'Carnal intercourse against the law of nature' is understood to be a derivative of distinct sexual orientation(s). For this argument, it is necessary to conceptualise and contrast sexual identities like heterosexual and homosexual. Just as the heterosexual is naturally inclined to penile-vaginal penetration, the homosexual is seen to be similarly inclined to 'carnal intercourse against the law of nature'. There is a claim of equality between the homosexual and the heterosexual as two different classes of people. In the human dignity argument, people who desire and indulge in 'carnal intercourse against the law of nature' are seen as a permanent minority. This minority is understood to have had a shared history of oppression, which in turn is seen to have brought them extreme disfavour and disrepute, hence a violation of their right to live with human dignity.

Of the case law that contributed to the three arguments, all cases without exception arose in the context of 'homosexual', 'gay and lesbian' people. The three arguments have done well in creating a language of sexual rights, but not without some generic limitations. There is a precondition of placing people into neat categories - heterosexual or homosexual, lesbian, gay or straight. In the privacy argument it is implicit that most people are heterosexual, there are a few who are not but they should be allowed their private space. The human dignity argument is founded on their seemingly cohesive minority status. It implies heterosexuals are the majority, and that there is a neat and clearly identifiable minority with a shared collective history. The equality argument places a homosexual on the same footing as a heterosexual, but the necessary comparator being the heterosexual. The underlying premise being that if the heterosexual does something, so can the homosexual. It is the heterosexual who sets the frame. The homosexual may borrow it, but is not allowed a new one.

Heterosexuality clearly emerges as the norm. Who set this norm? It is this heteronormativity that remains unchallenged in judicial human rights discourse. Far from being challenged, it is not even acknowledged.

\section{Beyond sexual identities}

There is a wide spectrum of gender and sexual identities in India. There are 'men who have sex with men' (MSM). Defying a strictly dichotomous gender identity, there are hijras who claim to be a third sex (Nanda 1990: 115). There are kothi men who display exaggerated feminine mannerisms, and prefer anal penetration by more masculine men. They also identify as non-English-speaking and coming from middle, lower income and working-class 
backgrounds (PUCL-K 2003). There are lesbian, gay, bisexual and transgender (LGBT) people, who in India are mostly urban, English-speaking, middle- and upper-middle-class men and women. In addition, each region of India has traditional identities that are based on practices of gender and sexual nonconformity (Narrain and Bhan 2005). Thus in India, the realities of the non-normative experiences, i.e. gender identities, sexual practices, sexual identities, culturally sanctioned forms of erotic behaviour, which contest the embedded nature of heterosexism, have traditionally existed and continue to exist in the contemporary context (Narrain and Bhan 2005).

Sexual diversity in India poses a challenge to the identity-based model implicit in the three legal arguments. Those who do not conform to prescribed sexual orientation identities will fall beyond its purview. For example, hijras could be men who crossdress, castrated men, or those who are intersexed. An indigenous identity, hijra is not a sexual identity but more of a gender identity - the 'third sex' as it is sometimes called. Neither man nor woman, a hijra's sexual acts (for instance, with men) then defy understanding through both heterosexual and homosexual categories. Further, as a community, hijras have a unique and indeed much longer history that cannot be so easily clubbed with the comparatively infantile LGBT identities in India. Lastly, in some regions, the sexual activity of hijras occurs in what are called hamams (public bath houses). Perhaps closest in comparison with brothels, the status of hamams in the privacy argument is left in the lurch. Another difficulty with privacy is that not everyone can afford it. hijras and kothi men who indulge in sex work often solicit on streets, leading to sex in public toilets or public parks. Far from toilet-fetish or the excitement of outdoor sex, this happens due to a lack of available 'private' spaces. Within the sanitisation of the privacy argument, where and how does one accommodate the realities of hijra lives? Is it best ignored because of the complexity hijras pose? What then of hijra's sexual rights; their human rights?

Although located squarely in the context of same sex sexualities and transgender identities, a broader premise common to the three arguments is sexual autonomy: that there is right to privacy of sexual expression, that sexuality should not be a ground for unjust discrimination, and that sexual conduct is part of the experience of being human - the three arguments acknowledge and endorse sexual diversity and autonomy. Notwithstanding its location in the same sex sexual identities, the generic potential of sexual autonomy is much wider. It is possible to present the world with a dynamic, pluralistic view of law, culture and sexuality that transcends the limitations of an identity-based model.

\section{The right to sexual autonomy}

Stephen Schulhofer defines sexual autonomy primarily in terms of the freedom to seek sexual fulfilment and freedom from sexual coercion. The right to sexual autonomy should include providing legal protection to permit individuals to identify with a particular gender identity or sexual orientation. Both the private and public aspects of one's sexual or gender identity should be protected as a legitimate choice of sexual self-determination (Katyal 2002). Using sexual autonomy as a conceptual framework avoids the problems of exclusion of the Indian men who have sex with men, for example, who are often left outside of categories of protection based on sexual orientation, because they might view themselves as heterosexual. This framework also harmoniously coexists with identity-based models. It is entirely possible to have a non-discrimination clause based on sexual orientation and to construe the right to privacy to include aspects of a person's sexual identity (Katyal 2002).

The language of international human rights is dynamic and is constantly expanding to articulate a rights-based approach to more and more issues. $A$ landmark break from the hierarchies of rights, human rights are now understood to be 'universal, indivisible, and interdependent and interrelated ...' Aspects of human life, be they health, livelihood, or shelter, are being increasingly articulated in a rightsbased language. Sexuality is an undeniable strand of human experience. Then, what keeps it from having its own place, its own articulation in the spectrum of human rights?

The human rights regime in India is also constantly expanding. Earlier thought to be located exclusively in civil and political rights (Part III of the Indian Constitution), rights later entered the practice of judicial intervention, and justiciability was extended to some of the socioeconomic rights (Part IV of the Constitution). Rights to privacy, health, livelihood and shelter were not articulated at the time of the framing of the Constitution but were later held to 
be a part of Article 21, which specifies the protection of life and personal liberty. ${ }^{13}$ Explicit constitutional guarantees are indeed far more stable and strong than Article 21, but the law is dynamic and must cater to changing times and emerging movements. The enthusiasm demonstrated by the Indian judiciary in expanding the language of human rights is preferable to the alternative of a rigid and stagnant body of human rights. In line with this enthusiasm, more and more could be read into the right to life and personal liberty. In that vein, there is a possibility that sexual autonomy could be read into

\section{Notes}

* I am grateful to Dr Robert Wintemute, School of Law, Kings College London for supervising my LLM (2002) full unit course essay. This article has emerged from that. I am also grateful to the human rights lawyer, Ms Nandita Haksar for her detailed comments; and to my colleagues at AMAN Trust: Richa Singh, with whom I had useful discussions and Dilip Simeon and Juhi Tyagi for their critical inputs on the draft; to my activist friends, Arvind Narrain and Pramada Menon for their timely and insightful comments; and to the Institute of Development Studies (IDS) for giving me the opportunity to present it to a wider audience at the workshop 'Realising Sexual Rights', 28-20 September 2005, which allowed me to gain valuable feedback, especially that from Sonia Corrêa and Susie Jolly.

1 A general comment states that " $\mathrm{t}$ ] his section is intended to punish the offence of sodomy, buggery and bestiality. The offence consists in carnal knowledge committed against the order of nature by a person with a man, or in the same unnatural manner with a woman, or by a man or woman in any manner with an animal'. A much older commentary, by Sir Hari Singh Gour states 'This section punishes what is "unnatural" carnal intercourse, and which is accounted a great crime since the destruction of Sodom and Gomorrah. But in spite of the high penalties to which it is justly subject, it is a crime which seldom comes to light, though it is notoriously widespread even in high society, and it is certainly not confined to any age or nationality, though it is a crime often detected amongst school boys and prisoners'. (Gour 1928: 1936)
Article 21; though it would really be better to articulate sexual autonomy as an explicit constitutional guarantee, in Part III of the Constitution.

A right to sexual autonomy would go a long way, not only in challenging 'carnal intercourse against the law of nature' and realising the rights of same sex sexualities and transgender identities, but also in evolving a rights-based approach to a whole spectrum of issues including gender, abortion, pleasure, sex work, sexual diversity and reproductive and sexual health.

2 'In various times and places everything from the ordinary heterosexual intercourse in an atypical position to oral contact with animals'. (Boswell 1980: 93)

3 'Lohana, Vasanthlal, Devchand vs State' (1962) All India Reporter, Gujrat: 252.

4 'Brother John Anthony vs The State' (1992) Criminal Law Journal: 1352.

5 'Grace Jayamani, Petitioner vs E.P. Peter, Respondent' (1982) All India Reporter, Karnataka: 46.

6 From an unpublished fact-finding report written by Elavarthi Manohar of the National Campaign on Sexuality Rights (NCSR), Tulika Srivastava of Association for Advocacy and Legal Initiatives (AALI), Lucknow, Jashodhara Dasgupta of Sahayog, Lucknow, Maya Sharma of Parma, Baroda, Vivek Divan, a human rights lawyer from Bombay and Arvind Narrain of the Alternative Law Forum, Bangalore. Some of the online published accounts of the incident can be accessed at: http://hrw.org/english/docs/2006/01/ 11/indial2398.htm and www.ilga.org/news_ results.asp?LanguagelD=1\&FileCategory=1\&Zonel $\mathrm{D}=3$ \& FilelD $=734$

7 'Dudgeon vs United Kingdom' (1981) Ser. A, No 45; 'Norris vs Ireland' (1988) Ser. A, No 142; 'Modinos vs Cyprus' (1993), Ser. A, No 259.

8 'Toonen vs Australia', (Communication No 488/1992) UN Doc CCPR/C/50/488/1992 (1994).

9 'Lawrence \& Garner vs State of Texas', www.supremecourtus.gov/opinions/02pdf/02102.pdf; also see decision of the Kentucky Supreme Court in 'Commonwealth of Kentucky vs Jeffrey Wasson', 842 SW 2d 487 (1992).

10 'National Coalition for Gay and Lesbian Equality vs The Minister of Justice', (1999) 1 SA 6. 
11 I have borrowed the first two from Wintemute's (1995: 17) classification. I have done away with Wintemute's third classification called 'sex discrimination argument', because none of the cases relevant to this essay bear any reference to this argument. I have replaced it with the human dignity argument, which has gained prominence in the South African judgement, 'National Coalition for Gay and Lesbian Equality vs The Minister of Justice' (1999) 1 SA 6.

\section{References}

Alexander, M. Jacqui (1997) 'Erotic Autonomy as a Politics of Decolonization. An Anatomy of Feminist and State Practice in the Bahamas Tourist Economy', in M.J. Alexander and C. Mohanty (eds), Feminist Genealogies, Colonial Legacies, Democratic Futures, New York: Routledge

Boswell, J. (1980) Christianity, Social Tolerance and Homosexuality: Gay People in Western Europe from the Beginning of the Christian Era to the Fourteenth Century, Chicago: University of Chicago Press Gour, H.S. (1928) The Penal Law of India, 4th edn, Vol II, Calcutta: Butterworth \& Co. (India) Ltd

The Hindu (2004) 'Delhi Schoolboy held in Phone Sleaze Case', 20 December, www.hindu.com/ 2004/12/20/stories/2004122008600100.htm (accessed 30 June 2006)

Kannabiran, K.G. (2004) The Wages of Impunity: Power, Justice and Human Rights, Hyderabad: Orient Longman

Katyal S. (2002) 'Exporting Identity', Yale Journal of Law and Feminism 14.1: 97-176

Macdougall, B. (2000) Queer Judgements: Homosexuality, Expression, and the Courts in Canada, Toronto: University of Toronto Press
12 World Conference on Human Rights, Vienna, 14-25 June 1993, www.unhchr.ch/huridocda/ huridoca.nsf/(Symbol)/A.CONF.157.23.En?Open Document

13 Constitution of India, Article 21: 'Protection of life and personal liberty. No person shall be deprived of his life or personal liberty except according to procedure established by law'.

Menon, N. (2005) 'How Natural is Normal? Feminism and Compulsory Heterosexuality', in A. Narrain and G. Bhan (eds), Because I Have a Voice: Queer Politics in India, New Delhi: Yoda Press

Nanda, S. (1990) Neither Man nor Woman: The Hijras of India, Belmont, CA: Wadsworth Publishing Company

Narrain A. (2004) Queer: Despised Sexuality, Law and Social Change, Bangalore: Books for Change

Narrain, A. and Bhan, G. (eds) (2005) Because I Have a Voice: Queer Politics in India, New Delhi: Yoda Press

PUCL-K (2003) Human Rights Violations Against the Transgender Community. A Study of Kothi and Hijra Sex Workers in Bangalore, India, Karnataka:

Peoples' Union for Civil Liberties, Karnataka (PUCL-K)

Ranchhoddas, R. and Thakore, D.K. (2002) The Indian Penal Code, 29th edn, Delhi: Wadhwa and Company

Wintemute, R. (1995) Sexual Orientation and Human Rights, Oxford: Clarendon Press

Wintemute, R. (1994) 'Sexual Orientation Discrimination', in G. Chambers and C. McCrudden (eds), Individual Rights and the Law in Britain, Oxford: Clarendon Press 